\title{
MENGKAJI \& MEMBANDINGKAN KURIKULUM 7 Negara ( Malaysia, Singapura, Cina, Korea, Jepang, Amerika dan Finlandia)
}

\author{
Armansyah Putra \\ Program Studi Pendidikan Biologi Universitas Samawa, Sumbawa Besar \\ Email: arman091088@gmail.com
}

\section{A. PENDAhuluan}

Pendidikan adalah salah satu komponen kehidupan yang paling urgen. Semenjak manusia berinteraksi dengan aktifitas pendidikan ini semenjak itulah manusia telah berhasil merealisasikan berbagai perkembangan dan kemajuan dalam segala lini kehidupan mereka. Bahkan pendidikan adalah suatu yang alami dalam perkembangan peradaban manusia. Secara paralel proses pendidikan pun mengalami kemajuan yang sangat pesat, baik dalam bentuk metode, sarana maupun target yang akan dicapai. Karena hal ini merupakan salah satu sifat dan keistimewaan dari pendidikan, yaitu selalu bersifat maju. Dan apabila sebuah pendidikan tidak mengalami serta tidak menyebabkan suatu kemajuan atau malah menimbulkan kemunduran maka tidaklah dinamakan pendidikan. Karena pendidikan adalah sebuah aktifitas yang integral yang mencakup target, metode dan sarana dalam membentuk manusia-manusia yang mampu berinteraksi dan beradabtasi dengan lingkungannya, baik internal maupun eksternal demi terwujudnya kemajuan yang lebih baik. Dalam rangka meningkatkan mutu pendidikan Indonesia, pemerintah terus berupaya melakukan berbagai reformasi dalam bidang pendidikan. Dan sebagai sarana untuk meningkatkan mutu pendidikan diperlukan sebuah kurikulum.

Studi perbandingan pendidikan dalam hal ini kurikulum merupakan salah satu cara untuk mengetahui berbagai aspek yang berhubungan dengan sistem pendidikan Indonesia dengan Negara tertentu, terutama yang berhubungan dengan kelebihan dan kekurangan yang terjadi pada sistem pendidikan tersebut. Untuk itulah pada kesempatan kali ini penulis mencoba mengkaji dan menguraikan perbandingan pendidikan terhadap beberapa Negara khususnya Indonesia, Amerika, Cina, Korea, Jepang dan Finlandia.

Sistem manajemen dari ke enam Negara ini terdapat kemiripan yaitu gabungan antara sentralistik dan desentralisasi. Kondisi ini sebenarnya sedikit berbeda dengan sistim pendidikan di Indonesia yang mana masalah sepenuhnya bersifat sentralistik tanpa memberi kewenangan kepada daerah untuk mengembangkan proses pendidikan, yang walaupun saat ini Indonesia sudah masuk dalam era desentralisasi tapi proses pengolahan pendidikan khususnya aspek anggaran daerah masih belum menaruh perhatian penuh terhadap pendidikan. Pernulis tertarik untuk mengkaji ke enam Negara ini di karenakan 
Negara ini memiliki karakteristik yang berbeda-beda baik dalam hal sector industry, ekonomi maupun pendidikan itu sendiri.

Makalah ini disajikan atas dasar kajian pustaka dari berbagai sumber yang relevan, untuk itu mengingat keterbatasan penulis makalah ini masih diperlukan masukan dan saran yang sifatnya konstruktif demi kesempurnaan makalah ini. Namun demikian penulis telah berusaha semaksimal mungkin untuk menyajikan makalah ini sehingga diharapkan akan dapat menambah bahan, wawasan dan kajian penulis tentang berbagai pemahaman sistem pendidikan dari ke enam Negara tersebut.

\section{B. KAJIAN TEORI}

\section{Pengertian Kurikulum}

Kurikulum (curriculum) merupakan suatu rencana yang memberi pedoman atau pegangan dalam proses kegiatan belajar mengajar”. Kurikulum dipahami sebagai seperangkat rencana dan pengaturan mengenai tujuan, isi, dan bahan pelajaran serta cara yang digunakan sebagai pedoman penyelenggaraan kegiatan pembelajaran untuk mencapai tujuan pendidikan tertentuKurikulum dipahami sebagai seperangkat rencana dan pengaturan mengenai tujuan,isi, dan bahan pelajaran serta cara yang digunakan sebagai pedoman penyelenggaraan kegiatan pembelajaran untuk mencapai tujuan pendidikan tertentu. (Sukmadinata : 2008). Kurikulum memiliki empat komponen, yaitu komponen tujuan, isi kurikulum, metode atau strategi pencapaian tujuan dan komponen evaluasi. Dalam sebuah kurikulum memuat suatu tujuan yang ingin dicapai dalam suatu sistem pendidikan. Untuk itu tujuan dalam suatu kurikulum memegang peranan yang sangat penting, karena tujuan mengarahkan semua kegiatan pengajaran dan mewarnai komponen-komponen kurikulum lainnya.

Dalam dimensi manajemen kurikulum, diperlukan koherensi antara kurikulum dengan pembelajaran yang dilakukan di lembaga pendidikan, yaitu : Pertama, kurikulum berpijak pada purposes or goal of the curriculum - tujuan kurikulum yang ingin dicapai. Kedua, kurikulum yang berpijak pada titik pandang berdasarkan konteks kurikulum yang digunakan. Ketiga, kurikulum bepijak pada titik pandang strategis tentang pengembangan kurikulum yang dipilih. Pengembangan juga tak dapat dipisahkan dengan proses, strategi pembelajaran yang dipilih, tehnik pembelajaran yang digunakan. Itulah sisi lain dari pandangan kurikulum sebagai proses (curriculum as a process). (Wahyudin, 2016)

Dalam perjalanan sejarah sejak tahun 1945, kurikulum pendidikan nasional telah mengalami perubahan, yaitu pada tahun 1947, 1952, 1964, 1968, 1975, 1984, 1994, 2004, 
2006 dan yang sekarang kurikulum 2013 yang walaupun belum merata disatuan pendidikan seluruh Indonesia diterapkan. Perubahan tersebut merupakan konsekuensi logis dari terjadinya perubahan sistem politik, sosial budaya, ekonomi, dan iptek dalam masyarakat berbangsa dan bernegara. Sebab, kurikulum sebagai seperangkat rencana pendidikan perlu dikembangkan secara dinamis sesuai dengan tuntutan dan perubahan yang terjadi di masyarakat. Semua kurikulum nasional dirancang berdasarkan landasan yang sama, yaitu Pancasila dan UUD 1945, perbedaanya pada penekanan pokok dari tujuan pendidikan serta pendekatan dalam merealisasikannya.

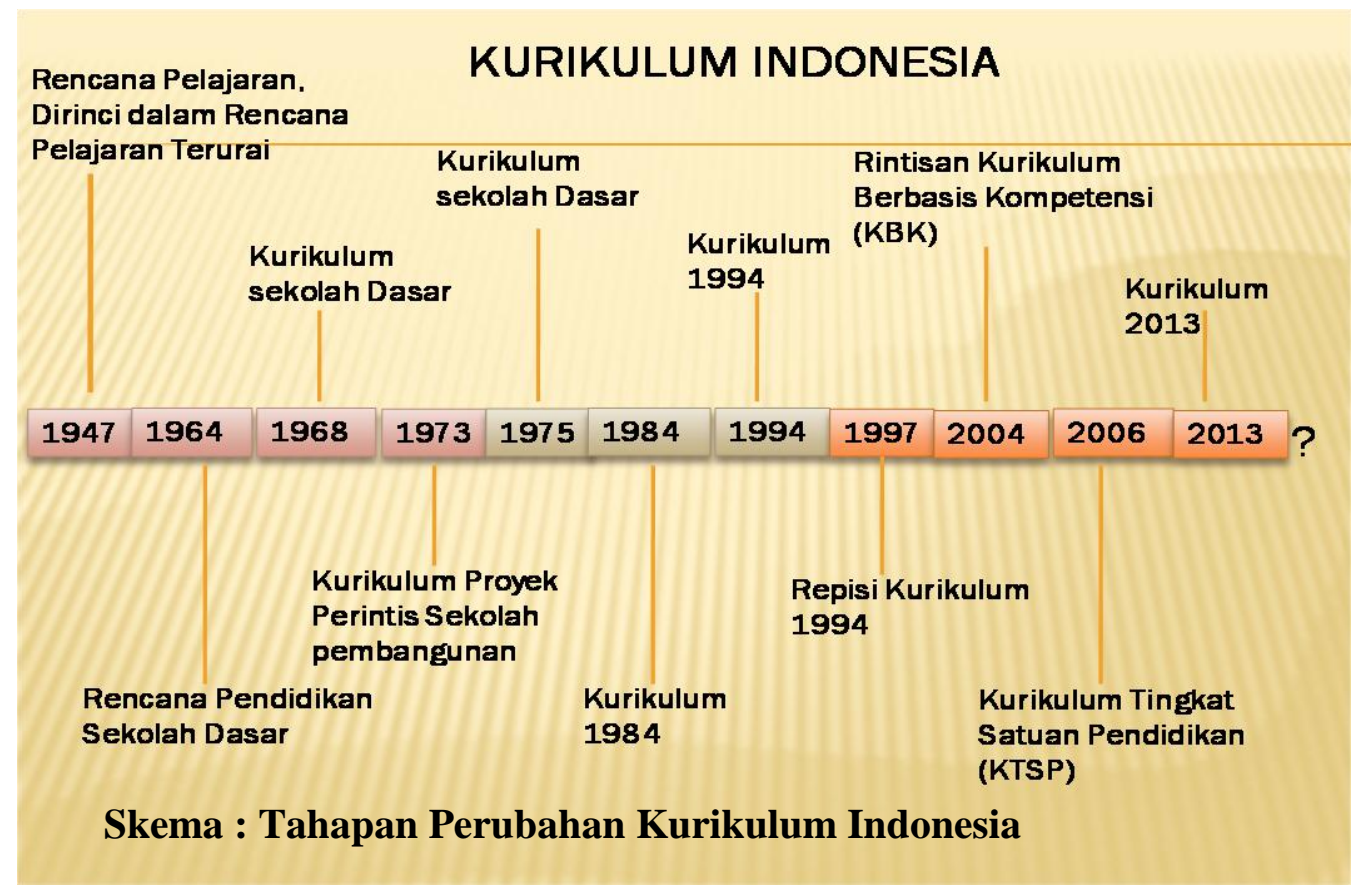

Kurikulum dapat dipahami dari tiga dimensi yakni kurikulum sebagai mata pelajaran, kurikulum sebagai pengalaman belajar, dan kurikulum sebagai rencana pembalajaran (Sanjaya, 2015). Kurikulum sebagai mata pelajar merupakan sejumlah mata pelajaran yang harus ditempuh untuk mendapati ijazah. Kurikulum sebagai pengalaman belajar merupakan seluruh pengalaman belajar yang harus ditempuh oleh peserta didik untuk mendapatkan ijazah, dan kurikulum sebagai rencana pembelajaran merupakan Kurikulum adalah seperangkat rencana dan pengaturan mengenai tujuan, isi, dan bahan pelajaran serta cara yang digunakan sebagai pedoman penyelenggaraan kegiatan pembelajaran untuk mencapai tujuan pendidikan tertentu.

Keikutsertaan Indonesia di dalam studi International Trendsin International Mathematicsand Science Study (TIMSS) dan Program for International Student Assessment (PISA) sejak tahun 1999 juga menunjukkan bahwa capaian anak-anak 
Indonesia tidak menggembirakan dalam beberapa kali laporan yang dikeluarkan TIMSS dan PISA. Hal ini disebabkan antara lain banyaknya materi uji yang ditanyakan di TIMSS dan PISA tidak terdapat dalam kurikulum Indonesia (Depdiknas, 2013).Pada studi TIMSS tahun 2011 lebih dari 95\% siswa Indonesia hanya sampai pada level menengah di bawah Malaysia, Thailand dan dan Saudi Arabia.

Menelaah lebih dalam tentang studi TIMSS ternyata banyak konten dalam kurikulum sains yang diujikan pada oleh TIMSS tetapi tidak terdapat dalam konten kurikulum yang ada di Indonesia, misalnya pada topik struktur partikular materi di dalam atom dan sifat dan penggunaan asam dan basa secara umum. Artinya perlu ada pembenahan dalam mengembangkan kurikulum di Indonesia agar sesuai atau tidak berbeda dengan struktur kurikulum internasional. Selain itu dalam mengembangkan kurikulum harus berawal dari pendekatan grassroots, seperti yang terjadi pada kurikulum di Amerika.

Pendekatan grass-roots merupakan pendekatan pengembangan kurikulum yang dirancang oleh guru dan bukan diberikan oleh pemerintah pusat (Print, 1998). Hal yang perlu diperhatikan dalam pendekatan ini adalah peningkatan kompetensi guru, karena tanpa guru yang memiliki kompetensi yang profesional maka pendekatan ini tidak akan berjalan. Salah satu model yang menggunakan pendekatan grassroots adalah model pengembangan kurikulum yang dikemukakan oleh Taba yaitu diagnosis of needs, formulation of objectives, selectioncontent, Organisation of content, selection of learningexperience, organisationof learningexperience, anddetermination of whattoevaluateandwayandmeans of doingit (Neil, 2010).

\section{Model-model kurikulum}

\section{Kurikulum Subjek Akademis}

Model kurikulum subjek akademis, yaitu model kurikulum tertua dan sangat praktis mudah disusun, dan mudah digabungkan, serta.mengutamakan isi (subject matter) yang merupakan kumpulan dari bahan ajar atau rencana pembelajaran.

Isi pendidikan diambil dari setiap disiplin ilmu. Sesuai dengan bidang disiplin para ahli, masing- masing telah mengembangkan ilmu secara sisematis, logis dan solid. Para pengembang kurikulum tidak susah- susah menyusun dan mengembangkan bahan sendiri. Mereka tingga memilih bahan materi ilmu yang telah dikembangkan para ahli displin ilmu, kemudian mengorganisasikan secara sistematis, sesuai dengan tujuan pendidikan dan tahap perkembangan siswa yang akan mempelajarinya. 
Ditinjau dari isinya, Sukmadinata (2005) mengklasifikasikan kurikulum model ini menjadi empat kelompok besar:

\section{a. Correlated curriculum.}

Pola organisasi materi atau konsep yang dipelajari dalam suatu peajaran dikorelasikan denga pelajaran lainnya.

\section{b. Unified atau concentrated curriculum}

Pola organisasi bahan peajaran tersusun dalam tema-tema pelajaran tertentu, yang mencakup materi dari berbagai pelajaran disiplin ilmu.

\section{c. Integrated curriculum}

Kalau dalam unified masih tampak warna disiplin ilmunya, maka dalam pola yang integrated warna disiplin ilmu tersebut sudah tidak kelihatan lagi. Bahan ajar diintegrasikan dalam suatu persoalan, kegiatan atau segi kehidupan tertentu.

\section{d. Problem Solving Curriculum}

Pola organisasi yang berisi topik pemecahan masalah sosial yang dihadapi dalam kehidupan dengan menggunakan pengetahuan dan keterampian yang diperoleh dari berbagai mata pelajaran atau disiplin ilmu. Pada kurikulum model ini, guru cenderung lebih banyak dimaknai sebagai seseorang yang harus "digugu" dan "ditiru". ada empat cara dalam menyajikan pelajaran dari kurikulum model subjek akademis.

- Materi disampaikan secara hierarkhi naik, yaitu materi disampaikan dari yang lebih mudah hingga ke materi yang lebih sulit. Sebagai contoh, dalam pengajaran pada jenjang kelas yang rendah diperlukan alat bantu mengajar yang masih kongkret. Hal ini dilakukan guna membentuk konsep riil ke konsep yang lebih abstrak pada jenjang berikutnya. Dalam Matematika, misalnya, konsep penjumlahan selalu disampaikan terlebih dahulu sebelum konsep perkalian, karena perkalian untuk bilangan bulat positif dapat dipandang sebagai penjumlahan berulang dari bilangan tersebut.

- Penyajian dilakukan berdasarkan prasyarat. Untuk memahami suatu konseptertentu diperlukan pemahaman konsep lain yang telah diperoleh atau dikuasai sebelumnya. Perhatikan $3 \times 4$, yang mempunyai makna $4+4+4$. Seseorang hanya bisa menghitung perkalian tersebut jika telah memahami dengan baik makna dari penjumlahan. Dengan demikian penjumlahan merupakan prasyarat untuk perkalian. 
- Pendekatan yang digunakan cenderung induktif, yaitu disampaikan dari hal-halyang bersifat umum menuju kepada bagian-bagian yang lebih spesifik.

- Urutan penyajian bersifat kronologis. Penyampaian materi selalu diawali denganmenggunakan materi-materi terdahulu. Hal ini dilakukan agar sifat kronologis/urutan materi tidak terputus.

\section{Karakteristik kurikulum :}

Kurikulum menekankan isi/materi ajaran

Isi kurikulum berasal dari disiplin ilmu (solid-sistematis)

Peranan guru sangat dominan

Penyajian : ekspositori \& inkuiri

\section{Kurikulum Humanistik}

Aliran ini lebih memberikan tempat utama kepada siswa. Bahwa anak itu memiliki potensi, punya kemampuan, dan punya kekuatan untuk berkembang. Prioritas pendekatan ini adalah pengalaman belajar yang diarahkan terhadaptanggapan minat, kebutuhan, dan kemampuan siswa. Pendekatan ini berpusat padasiswa dan mengutamakan perkembangan unsur afeksi. Pendidikan ini diarahkankepada pembinaan manusia yang utuh, bukan saja segi fisik dan intelektual, tetapijuga segi sosial dan afeksi (emosi, sikap, perasaan, nilai, dan lain-lain). Hal inimenandakan bahwa pendekatan ini berpegang pada prinsip peserta didik merupakansatu kesatuan yang menyeluruh. Pendidikan lebih menekankan bagaimana mengajarsiswa (mendorong siswa), dan bagaimana merasakan atau bersikap terhadap sesuatu.Penganut model kurikulum ini beranggapan bahwa siswa merupakan subjek utama yang mempunyai potensi, kemampuan dan kekuatan yang bisa dikembangkan. Hal ini sejalan dengan teori Gestalt yang mengatakan bahwa individu atau anak merupakan satu kesatuan yang menyeluruh (Sukmadinata: 2005:86). Pendidikan yang menggunakan kurikulum ini selalu mengedepankan peran siswa di sekolah. Dengan situasi seperti ini, anak diharapkan mampu mengembangkan segala potensi yang dimilikinya. Pendidikan dianggap sebagai unit proses yang dinamis serta merupakan upaya yang mampu mendorong siswa untuk bisa mengembangkan potensi dirinya. Karena itu, seseorang yang telah mampu mengaktualisasikan diri adalah orang yang telah mencapai keseimbangan perkembangan dari aspek kognitif, estetika, dan moral.Dalam proses 
penerapan di kelas, kurikulum humanistik menuntut hubungan emosinal yang baik antara guru dan siswa. Guru harus bisa memberikan layanan. yang membuat siswa merasa aman sehingga memperlancar proses belajar mengajar. Guru tidak perlu memaksakan segala sesuatu jika murid tidak menyukainya. Dengan rasa aman ini siswa akan lebih mudah menjalani proses pengembangan dirinya. Kurikulum humanistik merupakan kurikulum yang lebih mementingkan proses dari pada hasil. Sasaran utama kurikulum jenis ini adalah bagaimana memaksimalkan perkembangan anak supaya menjadi manusia yang mandiri. Proses belajar yang baik adalah aktivitas yang mampu memberikan pengalaman yang bisamembantu siswa untuk mengembangkan potensinya. Dalam evaluasinya, guru lebih cenderung memberikan penilaian yang bersifat subyektif.

\section{Kurikulum Rekontruksi Sosial}

Kurikulum ini lebih memusatkan pada problema-problema yang dihadapinya daam masyarakat. Kurikulum ini bersumber pada aliran pendidika internasional. Dalam aliran ini kurikulum merupakan sebuah kerjasama. Pandangan rekontruksi sosial di dalam kurikulum dimuai sekitar tahun1920-an. Harold Rug mulai melihat dan menyadarkan kawan- kawannya bahwa selama ini terjadi kesenjangan kurikulum dengan masyarakat. Ia menginginkan para siswa dengan pengetahuan dan konsepkonsep baru yang diperolehnya dapat mengidentifikasi dan memecahkan masalahmasalah sosial. Setelah diharapkan dapat menciptakan masyarakat baru yang lebih stabil.

Pada rekontruksionis tidak mau terlalu menekankan kebebasan individu. Mereka ingin meyakinkan murid-murid bagaimana masyarakat membuat warganya seperti yang ada sekarang dan bagaimana masyarakat memenuhi kebutuhan pribadi warganya melalui konsesus sosial. Perubahan sosial tersebut harus dicapai melaui prosedur demokrasi. Para rekontruksionis sosial menentang intimidasi, menakut nakuti dan kompromi semu. Mereka mendorong agar para siswa mempunyai pengetahuan yang cukup tentang masalah- masalah sosia yang mendesak ( crusial) dan kerja sama atau bergotong royong untuk memecahkannya.

Desain kurikulum Rekontruksi Sosial.

Ada beberapa ciri dari desain kurikulum ini:

a. Asumsi 
Tujuan utamanya adalah menghadapkan para siswa pada tantangan, ancaman, hambatan- hambatan atau gangguan- gangguan yang dihadapi manusia.

b. Masalah- masalah sosial yang mendesak

c. Pola- pola organisasi

Pola organisasi disusun seperti sebuah roda. Di tengah- tengah sebagai poros dipilih suatu masaah yang menjadi tema utama yang dibahas secara pleno. Topik- topik yang dibahas tersebut merupakan jari- jari. Semua kegiatan jari- jari tersebut dirangkum menjadi satu kesatuan sebagai bingkai.

- Komponen-komponen Kurikulum

Kurikuum rekontruksi sosial ini memiliki komponen- komponen yang sama dengan model kurikulum lain, namun isi dan bentuk- bentuknya berbeda.

1. Tujuan dan isi kurikulum

Bahwa tujuan serta isi kurikulum selalu mengalami perubahan setiap tahunnya hal ini disebabkan demi mengikuti perkembangan jaman serta kecanggihan teknologi yang ada.

2. Metode

Metode yang digunakan mementingkan minat dan bakat alami yang dimiliki oleh siswanya.

\section{Evaluasi}

Dalam evaluasi siswa dilibatkan. Keterlibatan mereka terutama dalam memilih, menyusun, dan menilai bahan yang akan diujikan

\section{KurikulumTeknologi}

Terdapat korelasi yang positif antara ilmu pengetahuan dan teknologi. Perkembangan ilmu pengetahuan akan berdampak positif terhadap teknologi yang dihasilkan. Demikian pula sebaliknya, kemajuan teknologi juga berpengaruh besar terhadap perkembangan ilmu pengetahuan, dan juga terhadap perkembangan model konsep kurikulum.

Penerapan teknologi dalam bidang pendidikan khususnya kurikulum adalah dalam dua bentuk, yaitu bentuk perangkat lunak ( software) dan perangkat keras ( hardware) penarapan teknologi perangkat keras dalam pendidikan dikenal sebagai teknologi alat (tools technologi), sedangkan penerapan teknologi perangjat lunak disebut juga teknologi sistem (system technologi). 


\section{Ciri-ciri kurikulum teknologi}

Tujuannya diarahkan pada penguasaan kompetensi, yang dirumuskan menjadi hasil belajar siswa. Tujuan yang masih bersifat umum dijabarkan menjadi tujuan-tujuan yang bersifat khusus, yang didalamnya terkandung aspek kognitif, afektif dan psikomotorik.

Metode pengajarannya bersifat individual, dimana setiap siswa mendapat tugasnya masing-masing sesuai dengan kemampuan tingkatbelajarnya. Siswa yang kecepatan belajarnya bagus, sedang maupun lambat mendapat perhatian semua. Tetapi tak menutup kemungkinan para siswa mendapat tugas yang bersifat kelompok untuk mengurangi rasa individual mereka supaya merangsang rasa sosialisasi. Penyampaian materi pada umumnya hanya penegasan kepada para siswa materi yang dipelajari, selanjutnya para siswa belajar mandiri dengan buku-buku dan bahan ajar lainnya.

Bahan ajar atau isi kurikulum diambil dari disiplin ilmu, dengan diramu sedemikian rupa sehingga memudahkan penguasaan suatu kompetensi. Bahan ajar yang besar disusun dari bahan ajar yang kecil sesuai dengan urutannya. Penjabaran seperti ini memudahkan penyampaian materi yang hendak dicapai. Sesuai dengan landasannya, kurikulum teknologi lebih ditekankan pada sifat ilmiah.

Evaluasi dapat dilakukan kapan saja, setelah siswa mendapat topik pelajaran siswa dapat mengajukan diri untuk dievaluasi. Fungsi evaluasi sebagai umpan balik untuk mengetahui tingkat kemampuan siswa dalam menerima dan memahami topik yang telah disampaikan. Bentuk evaluasi pada umumnya obyektifitas. Seperti halnya model kurikulum yang lain, model kurikulum ini memiliki kelebihan dan kekurangan. Pengajaran yang menggunakan alat-alat yang berhubungan dengan teknologi baru secara umum lebih menyenangkan. Dari sisi pelaksanaanya model pengajaran ini pengusaaan siswa jauh lebih tinggi dibandingkan dengan metode lain.

Namun demikian, model pengajaran ini memiliki keterbatasan. Model kurikulum ini kurang bias melayani siswa dengan bakat yang berbeda. Model ini cenderung seragam dengan menggunakan alat yang ada. Keberhasilan siswa tergantung pada teknologi dan juga perasaan mereka terhadap hal tersebut, bila tanggapan siswa positif maka pengusaan materi lebih cepat dan meningkat cepat pula.

Model kurikulum teknologi disesuaikan dengan pemikiran pendidikan. Model ini sangat mengutamakan penguasaan dan pembentukan kompetensi. Model kurikulum teknologi berorientasi pada masa sekarang dan yang akan datang, kurikulum ini juga 
menekankan pada isi kurikulum. Suatu kompetensi besar dijadikan kompetensi yang lebih kecil sehingga perilaku-perilaku siswa dapat diamati atau diukur.

Jenis teknologi
a. Teknologi cetak
b. Teknologi Audio-video
c. Teknologi berbasis komputer
d. Teknologi terpadu

\section{KAJIAN ANALISIS}

\section{Malaysia}

\section{a. Pendidikan Malaysia}

Sistem pendidikan di Malaysia diatur oleh Kementerian Pendidikan Malaysia (KPM). Pendidikan formal yang ada di malaysia dimulai dari Pra-sekolah, Pendidikan Rendah, Pendidikan Menengah, Pendidikan Pra-Universiti dan Pengajian Tinggi. Pendidikan merupakan tanggungjawab pemerintah federal. Sistem pendidikan nasional meliputi pendidikan prasekolah hingga perguruan tinggi. Pada tahun 2004 pendidikan prasekolah, dasar dan menengah berada dibawah yurisdiksi Kementrian Pendidikan (the Ministry of Education). Sedangkan pendidikan tinggi merupakan tanggungjawab Kementerian Pendidikan Tinggi (the Ministry of Higher Education). Semua bentuk penyelenggaraan pendidikan didasarkan pada visi dan misi. Adapaun visi dan misi utama pemerintahan Malaysia adalah menjadikan negerinya sebagai pusat pendidikan berkualitas dan siap bersaing dangan lembaga pendidikan tinggi di negara lain seperti Singapura dan Australia

\section{b. Manajemen Pendidikan}

Pada dasarnya sekolah di Malaysia dan Indonesia tidak jauh berbeda. Perbedaan yang menonjol dari pendidikan kedua negara tersebut pada nama jenjang kedua negara. Tingkatan jenjang pendidikan juga berbeda contohnya ada pada jenjang sekolah menengah dimana sekolah menengah Malaysia ditempuh dalam jenjang waktu 5 tahun sedangkan di Indonesia 6 tahun.

Negara Malaysia cenderung lebih maju di bidang pendidikan karena kurikulum yang dipakai baku dan tidak sering ada pergantian kurikulum. Berbeda dengan negara 
Indonesia yang sering terjadi pergantian kebijakan serta kurikulum sehingga pelaksana teknis di Indonesia lambat untuk berkembang.

Alasan lain yang berpengaruh dalam kemajuan pendidikan di kedua negara adalah bekas dari negara yang berbeda. Hal ini sedikitnya mempengaruhi sistem pendidikan di kedua negara.

\section{Singapura}

\section{a. Pendidikan Singapura}

Sistem pendidikan Singapura bertujuan untuk menyediakan pengetahuan dasar dan agama bagi murid - murid. Untuk menyatukan keberagaman karasteristik perbedaan ras dan budaya di Singapura, keberagaman bahasa, setiap siswa belajar Bahasa Inggris sebagai bahasa keseharian. Siswa juga belajar Bahasa Ibu mereka (China, Malaysia dan Tamil/ Thailand) untuk membantu mereka mempertahankan identitas, budaya, warisan, dan nilai-nilai bangsa.

Pendidikan formal di Singapura dimulai dari jenjang Kindergarten School atau setara dengan Taman Kanak-Kanak (TK) di Indonesia. Setelah lulus Kindergarten School, siswa melanjutkan ke jenjang Primary School atau setara dengan Sekolah Dasar (SD) di Indonesia selama enam tahun. Untuk menuju ke jenjang pendidikan yang lebih tinggi, siswa - siswa harus mengikuti Primary School Leaving Examination (PSLE). Kemudian pendidikan dilanjutkan ke jenjang Secondary School selama empat atau lima tahun. Secondary School dibagi menjadi empat jalur. Special/ Express Course, Normal (Academic) Course, Normal (Technical) Course, dan Integrated Programme (IP) Course. Special/ Express Course adalah empat tahun pendidikan yang diakhiri dengan Singapore Cambridge General Certificate of Education (GCE) 'O' Level Examination. Di jalur ini, siswa mempelajari Bahasa Inggris dan Bahasa Ibu, Matematika, Sains dan Budaya (Sosial). Sekolah diijinkan untuk menawarkan Applied Grade Subject (AGS) sebagai tambahan atau pengganti kurikulum untuk menawarkan berbagai pilihan kepada siswa. AGS secara umum mengajak murid untuk berlatih atau berorientasi pada pendidikan seperti politeknik.

\section{b. Manajemen Pendidikan}

Kemajuan pendidikan di Singapura didukung oleh banyak faktor. Diantaranya yaitu adanya fasilitas yang memadai. Contohnya, setiap sekolah di Singapura memiliki akses internet bebas. Setiap sekolah juga memiliki web sekolah yang berguna untuk menghubungkan siswa, guru, dan orangtua.. Selain itu, di setiap kelas terdapat Liquid 
Crystal Display (LCD) untuk proses pembelajaran. Fasilitas lainnya yaitu tersedianya sistem transportasi yang memiliki akses ke semua sekolah di Singapura yang memudahkan siswa untuk menuju ke sekolahnya. Faktor biaya juga sangat mempengaruhi kualitas pendidikan. Karena jika biaya sekolah murah, setiap orang di negara tersebut dapat mengenyam pendidikan dengan mudah. Di Singapura, biaya pendidikan disesuaikan dengan kemampuan rakyat, ditambah lagi dengan beasiswa bagi rakyat yang kurang beruntung. Faktor lain yang menyebabkan Singapura menjadi negara dengan sistem pendidikan terbaik di ASEAN adalah faktor pendidik. Proses penyaringan untuk menjadi guru sangat ketat dan calon guru yang diterima disesuaikan dengan jumlah guru yang diperlukan, sehingga semua calon guru tersebut pasti akan mendapatkan pekerjaan. Setelah teraudisi, para calon guru diberi pelatihan sebelum bekerja, sehingga guru-guru sudah mendapatkan pembekalan sebelumnya. Selain itu, gaji yang diberikan untuk guru-guru di Singapura juga banyak. Hal itu menyebabkan kehidupan guru-guru terjamin kesejahteraannya.

\section{Republik Rakyat Cina (RRC)}

\section{a. Pendidikan CINA}

Sistem pendidikan cina adalah meliputi : Pendidikan dasar (basic education), pendidikan teknik dan kejuruan (technical and vactional education), pendidikan tinggi (Higher education) dan Pendidikan orang dewasa ( adult education). Pendidikan dasar meliputi TK, SD, dan SM dengan lama pendidikan yaitu : Pra sekolah 3 tahun ke atas, sekolah dasar 5-6 tahun dengan usia masuk SD 6 tahun, dan pendidikan sekolah menengah tingkat pertama 3 tahun dan tingkat atas 5 tahun. Selain pendidikan formal dicina juga berkembang pendidikan non formal yang berupa pendidikan orang dewasa yang bertujuan untuk meningkatkan kualitas kehidupan masyarakat yang pada gilirannya diharapkan dapat member sumbangsi dalam pengembangan ekonomi penduduk. Selain itu dicina juga dikembangkan pendidikan literasi guna pemberantasan buta hurup (aksara).

\section{b. Manajemen pendidikan}

Sistem pendidikan cina adalah bersifat transentralisasi, artinya mulai dari level pusat, provinsi, kodiya, kabupaten dan termasuk daerah-daerah otonomi setingkat kodiya. Adapaun yang bertanggung jawab terhadap pelaksanaan pendidikan adalah komite pendidikan Negara (state education commission) yaitu organisasi professional pemerintah dalam bidang pembangunan pendidikan. Untuk biaya pendidikan tersedia 
pada pemerintah pusat dan daerah dengan distribusi, alokasi dari daerah khusus untuk pendidikan yang dikelolah oleh daerah sedangkan dana pusat untuk lembaga pendidikan yang berada di kementrian-kementrian.

Kurikulum dirumuskan oleh komisi pendidikan Negara yang sangat fleksibel serta bervariasi atas dasar kemampuan dan karakteristik wilayah, kota dan desa dan memberikan keleluasan bagi daerah untuk menambahkan kurikulum local. Dengan acuan sebagai berikut : SD memuat 10 mata pelajaran yang berbeda antara kota dan desa. Untuk SD pedesaan misalnya : memuat mata pelajaran pertanian selain mata pelajaran inti, moral, matematika dan bahasa cina. Sedangkan untuk SD perkotaan diwajibkan mata pelajaran olah raga. Sedangkan untuk sekolah menengah pertama memberikan 13 mata pelajaran termasuk diantaranya: pendidikan Moral, politik, bahasa cina, bahasa asing dan matematika. Sedangkan untuk SMA di sesuaikan dengan keinginan siswa (disesuaikan dengan kebutuhan masyarakat, serta kondisi lembaga setempat).

Sistem ujian dicina, untuk sekolah dasar dan menengah melaksanakan empat macam ujian yaitu ujian semester, ujian ujian tahunan, ujian akhir sekolah dan ujian masuk SMP, dan ujian-ujian ini hanya terbatas pada mata pelajaran bahasa cina dan matematika. Sedangkan ujian masuk SMA digabungkan dengan ujian akhir SMP. Untk masuk perguruan tinggi dilakukan ujian seleksi nasional dengan pemisahan antara sains dan ilmu social.

\section{Korea Selatan}

\section{a. Pendidikan Korea}

Salah satu keputusan Dewan Nasional Republik Korea tahun 1948 adalah menyusun undang-undang pendidikan. Sehubungan dengan hal ini, maka tujuan pendidikan Korea Selatan adalah untuk menanamkan pada setiap orang rasa Identitas Nasional dan penghargaan terhadap kedaulatan Nasional, menyempurnakan kepribadian setiap warga Negara, mengemban cita-cita persaudaraan yang universal, mengembangkan kemampuan untuk hidup mandiri dan berbuat untuk Negara yang demokratis dan kemakmuran seluruh umat manusia, dan menanamkan sifat patriotisme.

Secara umum system pendidikan di korea Selatan terdiri dari empat jenjang pendidikan formal yaitu : Sekolah dasar, Sekolah Menengah Tingkat Pertama, SLTA dan pendidikan tinggi. Keempat jenjang pendidikan ini adalah: grade 1-6 (SD), grade 
7-9 (SLTP), 10-12 (SLTA), dan grade 13-16 (pendidikan tinggi/program S1), serta program pasca sarjana (S2/S3).

Visualisasi grade pendidikan yang dimaksud adalah:

a. Sekolah dasar merupakan pendidikan wajib selama 6 tahun bagi anak usia 6 dan 11 tahun, dengan jumlah lulusan SD mencapai 99,8\%, dan putus sekolah SD 0,2\%.

b. SMP merupakan kelanjutan SD bagi anak usia 12-14 tahun, selama 3 tahun pendidikan.

c. Kemudian melanjutkan ke SLTA pada grade 10-11 dan 12, dengan dua pilihan yaitu: umum dan sekolah kejuruan. Sekolah kejuruan meliputi pertanian, perdagangan, perikanan dan teknik. Selain itu ada sekolah komperhensif yang merupakan gabungan antara sekolah umum dan sekolah kejuruan, yang merupakan bekal untuk melanjutkan ke akademik (yunior college) atau universitas (senior college).

d. Pendidikan tinggi/akademik (yunior college) atau universitas program S1 (senior college), pada grade 13-16, dan selanjutnya ke program pasca sarjana (graduate school) gelar master/doktor.

\section{b. Manajemen Pendidikan}

Kekuasaan dan kewenangan dilimpahkan kepada menteri pendidikan. Di daerah terdapat dewan pendidikan. Pada setiap provinsi dan daerah khusus (seul dan busam) masing-masing dewan pendidikan terdiri dari tujuh orang anggota dan dipilih oleh daerah otonom. Anggaran pendidikan korea selatan berasal dari angarn Negara, dengan total anggaran 18, 9 \% dari anggaran Negara. Pada tahun 1995 ada kebijakan wajib belajar 9 tahun, sehingga forsi anggaran terbesar diperunttukkan program tersebut. Adapun sumber pendidikan dari pajak pendidikan, keuangan pendidikan daerah, dunia industry khusus bagi pendidikan kejuruan.

Reformasi kurikulum pendidikan di korea dilaksanakan sejak tahun 1970 dengan mengkoordinasikan pembelajaran teknik dalam kelas dan pemanfaatan teknologi, adapun yg dikerjakan oleh guru meliputi lima langkah yaitu : perencanaan pengajaran, diagnosis murid, membimbing siswa belajar dengan berbagai program, tes dan menilai hasil belajar. Disekolah tingkat menengah tidak diadakan tes masuk hal ini dikarenakan ada kebijakan equel accesbility atau kesekolah menengah di daerahnya. 


\section{Jepang}

\section{a. Pendidikan Jepang}

Sebelum perang dunia II, sistem pendidikan jepang memiliki banyak jalur, namun setelah tahun 1980 pemerintah jepang melakukan reformasi di bidang pendidikan. Taman kanak-kanak (TK) menerima anak berusia 3-5 tahun, sedangkan pendidikan dasar (SD) menerima siswa yg berusia 6 tahun dengan jumlah mata pelajaran bervariasi yaitu 850 jam pelajaran /tahun. Sedangkan untuk pendidikan menengah pertama berlangsung selama tiga tahun dengan jumlah jam pelajaran 1015/tahun.

Tingkatan pendidikan di Jepang sama dengan di Indonesia yaitu dengan menggunakan sistem 6-3-3 (6 tahun SD, 3 tahun SMP, tiga tahun SMA) dan Perguruan Tinggi. Pendidikan Sekolah Dasar dan Sekolah Menengah Pertama digolongkan sebagai Compulsory Education dan Sekolah Menengah Atas digolongkan sebagai Educational Board.

Di Jepang Pendidikan dasar tidak mengenal ujian kenaikan kelas, tetapi siswa yang telah menyelesaikan proses belajar di kelas satu secara otomatis akan naik ke kelas dua, demikian seterusnya. Ujian akhir juga tidak ada, karena SD dan SMP masih termasuk kelompok compulsory education, sehingga siswa yang telah menyelesaikan studinya di tingkat SD dapat langsung mendaftar ke SMP. Selanjutnya siswa lulusan SMP dapat memilih SMA yang diminatinya, tetapi kali ini mereka harus mengikuti ujian masuk SMA yang bersifat standar, artinya soal ujian dibuat oleh Educational Board. (Nur. 2010)

\section{b. Manajemen Pendidikan}

Pada level nasional tanggung jawab pendidikan ada pada kementrian pendidikan,

ilmu pengetahuan dan kebudayaan. Kementrian memberikan pedoman untuk menyusun kurikulum mata pelajaran serta persyaratan kredit mulai dari TK hingga ke perguruan tinggi. Kementrian juga bertanggung jawab terhadap pengembangan buku teks untuk sekolah dasar dan menengah. Kemudian distrik terdapat dewan pendidikan yang bertanggung jawab terhadap suvervisi atas masalah-masalah personalia pada lembaga pendidikan pemerintah, memberikan inservice training asset cultural, dan memberikan nasihat kepada lembaga-lembaga pendidikan. Di masing-masing kota memiliki tiga sampai lima orang dewan pendidikan dengan fungsi utama memberikan dan mengurus institusi pendidikan di kota. Sistem keuangan di jepang disediakan 
bersama-sama antara pemerintah pusat, distrik, maupun kota, dimana diambil dari pajak dan dari sumber-sumber lain.

Kurikulum sekolah ditentukan oleh menteri pendidikan yang kemudian dikembangkan oleh dewan pendidikan distrik dan kota. Pada semua tingkat pendidikan di jepang harus menempuh berbagai ujian yang merupakan syarat untuk naik kelas atau untuk mendapatkan ijazah. Bagi siswa yang kehadirannya kurang dari $5 \%$ tahun belajar dan hasil ujian jelek maka diwajibkan untuk mengulang pada level yang sama. Kurikulum disusun oleh sebuah komite khusus dibawah control kementrian pendidikan (MEXT). Komisi kurikulum terdiri dari praktisi dan pakar pendidikan , wakil dari kalangan industry dan wakil MEXT. Komisi ini bertugas mempelajari tujuan pendidikan jepang yang terdapat dalam fundamental education law lalu menyesuaikan dengan perkembangan yang terjadi baik di dalam maupun luar negeri. Pembaharuan krikulum jepang setiap 10 tahun sekali.

\section{Amerika Serikat}

\section{a. Pendidikan Amerika Serikat}

Jenjang pendidikan di Amerika Serikat biasanya dimulai dari preschool, kindergarten, atau first grade; setelah itu Elementery (or Primary) School-dalam hal ini, siswa dapat memutuskan untuk pindah ke Middle School, Junior High School, atau Combined Junior-Senior High School; selanjutnnya ada High School atau Senior High School. Dan untuk pendidikan tingginya, ada Vocational Technical Institutes, Junior or Community College, atau Undergraduated Program. Setelah menyelesaikan pendidikan tinggi, seseorang dapat melanjutkan ke Master's Degree Study atau Professional School. Selanjutnya ada Doctoral Study dan Post Doctoral Study and Research.

Jalur pendidikan di Amerika Serikat adalah formal dan informal. Pendidikan formal adalah seperti yang telah dijelaskan di atas, sementara pendidikan informal adalah homeschooling. Menurut wikipedia.com/Education in United States, tahun 2007, kirakira ada 1,5 juta anak yang mengikuti mengikuti home schooling. Ada berbagai alasan dari homeschooling ini. Beberapa mengatakan agar mereka bisa memasukkan pelajaran agama pada kurikulum. Sementara yang lain mengatakan untuk menyesuaikan anak-anak pada kemampuan dan kelemahannya. Dan lagi beberapa orangtua mengatakan untuk menghindari anak-anak dari tekanan negatif sekolahsekolah, seperti obat-obatan terlarang, kekerasan dan semua masalah yang 
berhubungan dengan sekolah. Sementara Jenis pendidikannya adalah pendidikan umum dan swasta.

\section{b. Manajemen pendidikan}

Kurikulum di Elementary School adalah Aritmatika Dasar, Matematika, bahasa Inggris (seperti Grammar, Speeling dan vocabulary), dan mata pelajaran lainnya seperti pelajaran sosial, pengetahuan alam, pengembangan fisik, kesenian dan membaca. Sementara di Junior dan Senior High School, kurikulum dasarnya adalah Ilmu Alam (Biologi, Kimia dan Fisika), Matematika (Algebra, Geormetri, praKalkulus, Statistik, dan Kalkulus), Bahasa Inggris (Sastra, Kemanusian, Komposisi dan bahasa lisan), Ilmu Sosial (Sejarah, Pemerintaha dan Ekonomi). Siswa High School juga memiliki mata pelajaran pilihan seperti Atletik, Karir dan Pendidikan teknik, pelajaran Komputer, Bahasa Asing dan beberapa mata pelajaran lain yang bisa menunjang keberhasilan anak dan diminati oleh siswa tersebut. Guru di Amerika Serikat haruslah memiliki sertifikat mengajar dari pemerintah atau pendidikan tinggi untuk bisa mengajar baik di preschool atau di sekolah menengah. Sertifikat itu adalah seperti Postgraduate Certificate in Education, Profesional Graduate Diploma dan Bachelor of Education. Menurut artikel yang ditulis oleh Shane Lopes dan Preety Sidhu yang berjudul U.S Teacher Love Their Lives, but Struggle in the Workplace, dalam gallup.com/poll, pekerjaan sebagai guru beada dalam urutan delapan dari 14 jenis pekerjaan yang dicari. Ini membuktikan bahwa guru merupakan pekerjaan yang dicari orang. Dan menurut wikipedia.com/Education in United States, gaji guru pada tahun 2011 adalah 55,040 dollar.

\section{Finlandia.}

\section{a. Pendidikan Finlandia}

Tujuan utama dari kebijakan pendidikan Finlandia adalah semua warga mendapatkan kesempatan yang sama dalam hal menerima pendidikan, tanpa memperhitungkan usia, tempat tinggal, situasi keuangan, jenis kelamin atau orang tua. Pendidikan dianggap sebagai salah satu hak-hak dasar semua warga negara.

Pertama, ketentuan tentang pendidikan dasar menjamin hak setiap orang untuk mendapatkan pendidikan dasar secara gratis, yang juga merupakan ketentuan wajib belajar. Kedua, pejabat publik juga berkewajiban untuk menjamin setiap orang berkesempatan sama dalam memperoleh pendidikan lainnya selain pendidikan dasar sesuai dengan kemampuan dan kebutuhan khusus, dan untuk mengembangkan diri 
agar terhindar dari kesulitan ekonomi. Pejabat publik wajib menyediakan untuk kebutuhan pendidikan di Finlandia (edu.fi,2009). Jenjang Pendidikan di Finlandia meliputi : Pra pendidikan dasar, Pendidikan dasar dan menengah, Tertiary pendidikan, Pendidikan tinggi, dan Pendidikan dewasa.

\section{b. Manajemen Pendidikan}

Setiap guru di Finlandia minimal harus bergelar master alias S2. Hanya 11 universitas yang memiliki program pendidikan guru, jadi memudahkan dalam mengontrol kualitas dan standar konsistensi program pendidikan. Untuk mendapat gelar master, mahasiswa harus menyelesaikan 5 tahun pendidikan research-based yang menekankan pengetahuan tentang pedagogic. Sebelum lulus mahasiswa juga harus mengikuti magang selama satu tahun penuh mengajar di sekolah yang bekerja sama dengan universitas tempat mereka kuliah. Sekolah-sekolah ini adalah sekolah model, dimana para guru dan peneliti mengembangkan metode-metode baru dan menyelesaikan penelitian mengenai belajar mengajar.

Dalam hal kurikulum, pemerintah hanya membuat panduan umum berupa target (goals). Dan guru diberi kebebasan bagaimana caranya untuk mencapai target tersebut. Guru bebas memakai metode mengajar maupun buku teks apa pun. Guru mengajar kelompok siswa yang sama sampai beberapa tahun. Dengan demikian, guru dapat lebih mengenal siswa-siswanya sekaligus dapat memantau perkembangan akademik, sosial dan emosionalnya. Dan setiap guru wajib membuat evaluasi mengenai perkembangan belajar setiap siswanya. Dan satu kelas maksimal jumlah siswa hanya 12 orang sehingga guru dapat lebih mudah memantau seluruh siswanya. Tidak ada standarisasi pendidikan di Finlandia karena berlawanan dengan kreatifitas. Mereka percaya semakin standarisasi ditekankan, semakin sempit ruang kreatifitas. Menurut guru di Finlandia, mata pelajaran terpopuler di kalangan siswa adalah art \& craft terutama kerajinan kayu (woodwork). Selain itu, guru di Finlandia menekankan pentingnya waktu bermain, yang dipercaya dapat meningkatkan performa akademik siswa, membantu perkembangan kognitif, afektif dan sosial. Prinsipnya dalam 1 jam pelajaran, 45 menit dialokasikan untuk belajar dan 15 menit untuk bermain bebas sesuai kehendak siswa. Karenanya, waktu istirahat sangat banyak di sekolah-sekolah Finlandia bahkan hingga sekolah lanjutan atas. Guru mengurangi mengajar dengan metode ceramah dengan persentase $40 \%$ guru dan 60\% siswa. Wajib belajar adalah 9 tahun. Tidak memberlakukan pemisahan pendidikan dasar dan lanjutan sehingga tidak 
perlu berganti sekolah di usia 13 tahun. Kebijakan ini dilakukan untuk menghindari masa transisi yang perlu dialami oleh siswa, yang dianggap dapat mengganggu pendidikan mereka.

\section{KESIMPULAN}

Dari hasil kajian dan pembahasan tentang perbandingan kurikulum dari 8 negara yaitu : Indonesia, Malaysia, Singapura, Cina, Korea, Jepang, Amerika dan Finlandia dapat disimpulkan bahwa, dari ke 8 negara tersebut sistim manajemen bersifat gabungan antara desentralisasi dan sentralistik. Kurikulum Masing-masing negara disusun oleh kementrian pendidikan, selanjutnya sekolah diberikan kewenangan untuk menyusun kurikulum/menambah kurikulum lokal sesuai dengan kondisi wilayah masing-masing dan permintaan siswa.

Hal ini berbeda dengan negara indonesia, yang memasukkan kurikulum local namun tidak berhubungan langsung dengan permintaan siswa, seperti kurikulum lokal yang hanya terbatas pada bahasa daerah, seni dan lain-lain.

Untuk memberikan peluang masa depan pada siswa, kiranya system kurikulum hendaknya lebih fleksibel dan daerahpun agar memasukkan kurikulum local yang bersifat "kreatifitas" sesuai kondisi daerah masing-masing, seperti kurikulum local pertanian, perikanan, perkebunan.teknologi dan lain- lain, tidak hanya sebatas kurikulum seperti bahasa daerah atau bahasa asing yang selama ini banyak dimunculkan sehingga, mtidak berpengaruh terhadap lapangan kerja dan tidak meberikan jaminan untuk kehidupan.pekerjaan siswa setelah tamat sekolah.

Hal ini, penulis munculkan, karena ternyata diketiga Negara ini cukup berhasul dengan kurikulum local yang mereka pilih berupa pertanian, perikanan, dan teknologi industri dan lain-lain, ini terbukti dengan banyaknya 
kerajinan industri yang bersifat home industri di ketiga Negara ini, sehingga

pada gilirannya akan berimplikasi kepada pertumbuhan ekonomi Negara dan kesejahteraan masyarakatnya semakin bertambah. 


\section{REFERENSI}

Departemen Pendidikan Nasional Republik Indonesia. Undang-undang Republik Indonesia Nomor 20 Tahun 2003 tentang Sistem Pendidikan Nasional. Jakarta:2003.

Wahyudin, D. (2016). Manajemen Kurikulum Dalam Pendidikan Profesi Guru (Studi Kasus Di Universitas Pendidikan Indonesia). Jurnal Kependidikan Volume 46 No. 2.

Marlow-Ferguson, R. (Ed.). (2002). World Education Encyclopedia: A Survey of Educational Systems Worldwide, Vol. 1 (2nd ed.). Farmington Hills, MI: Gale Group.

Neil, G.O. Program desing: overview of curriculum models. Fingal: UCD Teaching.

Nur. 2010 . Potret pendidikan di jepang sebagai konsep pencerahan pendidikan di indonesia. Jurnal MEDTEK, Volume 2, Nomor 1

Peraturan menteri pendidikan nasional nomor 70 Tahun 2013 tentang kerangka dasar dan struktur kurikulum sekolah menengah kejuruan/madrasah aliyah kejuruan

Print, M. (1998). Curriculumdevelopmentanddesign. Sydney: Allen \&Unwin

Oliva, Peter. F. (1992) Developing the Curriculum 3rd ed. Harpers Collins Publisher. New York.

Sukmadinata, Nana S. (2008). Pengembangan Kurikulum: Teori dan Praktek. Remaja Rosdakarya : Bandung. 